\title{
Effect of hyperbaric oxygen therapy on esophagojejunal anastomosis healing in rats ${ }^{1}$
}

\author{
O efeito da oxigenoterapia hiperbárica na cicatrização da anastomose esofagojejunal em ratos
}

\author{
João Domingos Lionço", Lívia Caprara Lionço" ${ }^{I}$, Lucas Torely Filippi ${ }^{I I}$, Clarissa Caprara Lionço" ${ }^{\text {II }}$ Bernardo Volkweiss ${ }^{\mathrm{II}}$, \\ Richard Ricachenevsky Gurski ${ }^{\text {IV }}$
}

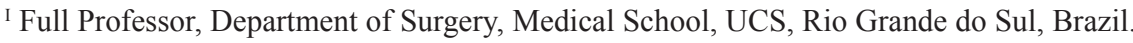

II Graduate student, Medical School, UCS, Rio Grande do Sul, Brazil.

${ }^{\text {III }}$ MS, Department of Surgery, Federal University of Rio Grande do Sul (UFRGS), Brazil

Iv PhD, Department of Surgery, UFRGS, Brazil.

\begin{abstract}
Purpose: To evaluate hyperbaric oxygen therapy (HBO) after esophagojejunal anastomosis in a rat experimental model and the effect of HBO on the healing of esophagojejunal anastomosis in gastrectomized rats. Methods: Forty adult male Wistar rats, weighing $322 \mathrm{~g}$ to $506 \mathrm{~g}$, were divided into two random groups. In group A (control group), 20 rats were subjected to total gastrectomy. In group B, 20 rats were similarly gastrectomized, but also received postoperative HBO treatment for 90 minutes/day for seven days. All rats were sacrificed on the eighth postoperative day and evaluated according to the following study variables: a) presence of anastomotic fistula; b) evaluation of esophagojejunal anastomosis healing by measuring the breaking strength at the suture line as per Hendriks \& Mastboom; and c) determining the collagen concentration in the anastomosis, as per Kovács criteria. For the comparative statistical analysis between groups, Student's " $t$ " test was used. A value of $p<0.05$ was considered significant. Results: There was a $20 \%$ mortality rate. There were five deaths in group A and three in group B ( $p=N$.S.). There was only one anastomotic fistula in each group, and neither caused any morbidity or death. Breaking strength measured at the suture line $(p=0.528)$ and collagen concentration determined at the esophagojejunal anastomosis $(p=0.89)$ were not significantly different between Groups A and B. Conclusion: Hyperbaric oxygen therapy did not affect the healing process of esophagojejunal anastomosis. Key words: Anastomosis, Surgical. Collagen. Tensile Strength. Oxygen Inhalation Therapy. Rats.
\end{abstract}

\section{RESUMO}

Objetivo: Avaliar o efeito da oxigenoterapia hiperbárica na cicatrização da anastomose esôfagojejunal em ratos gastrectomizados. Métodos: 40 ratos Wistar, adultos machos, pesando entre $322 \mathrm{~g}$ e $506 \mathrm{~g}$, foram divididos aleatoriamente em dois grupos. No grupo A (grupo controle) 20 ratos foram submetidos à gastrectomia total. No grupo B, 20 ratos foram gastrectomizados e receberam tratamento pós-operatório com oxigênio hiperbárico, 90 minutos/dia durante sete dias. Todos os ratos foram sacrificados no oitavo dia pós-operatório e avaliados de acordo com as seguintes variáveis: a) presença de fístula anastomótica; b) avaliação da cicatrização da anastomose esôfagojejunal pela medida da força de ruptura à tração na linha da sutura conforme Hendriks \& Mastboom; c) determinação da concentração de colágeno na anastomose pelos critérios de Kovács. Para análise estatística comparativa entre os grupos foi utilizado o teste " $t$ " de Student, considerando-se como significativo o valor de $p=0.05$. Resultados: A mortalidade foi de $20 \%$. Morreram cinco ratos do grupo A e tres do grupo B ( $\mathrm{p}=$ N.S.). Ocorreu uma fístula anastomótica em cada grupo não relacionadas a óbito. A medida da força de ruptura à tração na linha da sutura $(\mathrm{p}=0.528)$ e a determinação da concentração de colágeno na anastomose esôfagojejunal $(\mathrm{p}=0.89)$ não mostrou diferença estatisticamente significativa entre os grupos A e B. Conclusão: A oxigenoterapia hiperbárica não interferiu no processo de cicatrização da anastomose esôfagojejunal. Descritores: Anastomose Cirúrgica. Colágeno. Resistência à Tração. Oxigenoterapia. Ratos.

${ }^{1}$ Research performed at the Laboratory of Physiology, Medical School, Caxias do Sul University (UCS), Rio Grande do Sul, Brazil.

\section{Introduction}

Surgeries to reestablish digestive flow, particularly procedures specifically involving esophageal anastomosis, still represent a considerable challenge to the surgeon due to a high risk of complications brought about by anastomosis in that organ ${ }^{1-2}$.
Anatomical and physiological peculiarities are responsible to the complexities in the healing process after surgeries on the esophagus. Blood flow in the esophagus is poor; apart from this, esophageal fibers are longitudinally arranged in thin walls, and the organ does not have a serous membrane. These are key aspects behind the high occurrence of anastomotic fistula, which occurs 
on average in $20 \%$ of all esophageal surgical procedures. Also, anastomotic fistula is the most important cause of postoperative complications expressed either in terms of morbidity or mortality ${ }^{3}$.

Local factors such as the surgical technique, blood flow, tension of the sutures, bacterial contamination, and systemic factors such as malnutrition, collagen metabolism, and infection all contribute to the slow or unsuccessful healing of this class of surgical procedure ${ }^{4-6}$.

In spite of better knowledge of clinical, metabolic, nutritional, and infectious phenomena, esophageal anastomotic dehiscence still occurs in $20 \%$ to $25 \%$ of cases. Several studies have assessed the results of different esophageal suture techniques. Alternative manual techniques, mechanical sutures, the use of biofragmentable rings, and collagen anastomotic reinforcements have been tested in animals. Unfortunately, these techniques were unsuccessful in reducing the failure rates in procedures to treat anastomosis, an observation which shows that current treatment approaches are inadequate to provide an effective surgical solution ${ }^{3,5-7}$.

Tissue ischemia is one of the most important factors linked to poor healing, and ultimately leads to the emergence of anastomotic fistula. Under these conditions, increased oxygen could reverse hypoxia, avoid the adverse effects of ischemia, and speed up the healing process. In the various possible clinical scenarios, one of the methods to increase oxygen levels is hyperbaric oxygen therapy $(\mathrm{HBO})^{8}$. More specifically, a MEDLINE review of the available literature concerning the use of $\mathrm{HBO}$ in anastomosis in the alimentary tract retrieved two papers, both addressing colic anastomosis experimentally induced in rats ${ }^{9-10}$. However, no paper on the use of HBO to treat esophageal anastomosis was found.

This study evaluated the effect of HBO on esophagojejunal anastomosis in gastrectomized rats by measuring the number of anastomotic fistula, suture breaking strength, and collagen concentration in the anastomotic site, using an experimental model.

\section{Methods}

Forty male Wistar rats, weighing 322 to $506 \mathrm{~g}$, were used. Rodent management followed the Guide for the Care and Use of Laboratory Animals, National Institutes of Health. Animals were randomized into two groups of 20 animals each (Groups A and B). Animals in Group A (control) underwent total gastrectomy, while animals in Group B underwent total gastrectomy and then subsequently treated with HBO. Animals were given water and food ad libitum throughout the experimental period, except for the 12-h period before and 24-h period after surgery, when only water was offered.

\section{Surgical procedure}

All animals were anesthetized with a single $30-\mathrm{mg} / \mathrm{kg}$ IM dose of tiletamine/zolazepam (Telasol). A single $30-\mathrm{mg} / \mathrm{kg}$ dose of sodium ampicillin was also administered intramuscularly. After a $3-\mathrm{cm}$ median laparotomy, total gastrectomy ensued, with isoperistaltic terminolateral esophagojejunostomy conducted with a simple interrupted stitch using polypropylene monofilament wire 7-0. The abdominal wall was sutured using polypropylene monofilament wire 4-0. For re-hydration, all rats received subcutaneous injections of $10 \mathrm{~mL}$ warm saline solution. On postoperative day 8 , the animals were sacrificed using a lethal dose of halothane and subsequently necropsied. Rats that died before the end of the study were also necropsied.

\section{HBO treatment}

Rats from Group B were placed in an experimental hyperbaric chamber in which pure oxygen was administered at a 2.5 ATA pressure in a 90-minute session. Sessions started on postoperative day 1 and were conducted once a day, always at the same time, for seven days.

\section{Fistula in esophagojejunal anastomosis}

After the necropsy of the rats, the surgical section to be studied was removed and a macroscopic inspection of the suture was conducted. Fistula was defined as the presence of leaking next to the anastomotic site and/or perianastomotic abscess blocking the fistulous orifice.

\section{Measurement of tensile suture breaking strength}

This test measured the strength needed to break the suture longitudinally. A dynamometer was coupled to the surgical section containing the anastomosis. The surgical section was pulled at both ends at a continuous and constant speed of $1 \mathrm{~cm} / \mathrm{min}^{5}$. Breaking strength was defined as the strength needed to break the suture as indicated by the dynamometer.

\section{Establishment of collagen concentration in the anastomotic site}

Once an anastomosis broke off, the perianastomotic esophageal tissue was placed in $10 \%$ formaldehyde. Next, surgical sections were imbedded in paraffin and sliced to $4-\mu \mathrm{m}$ thick specimens using a microtome. Section specimens were mounted on slides and stained with hematoxylin-eosin and picrosirius red. Specimens were visualized under a light microscope under polarized light at $\mathrm{x} 400$, as outlined in Rabau and Dayan ${ }^{11}$.

Two criteria were established to evaluate the biochemical parameters, and were measured semi-quantitatively by the percentage of fibrotic areas involved in the healing process. The first criterion was defined by the proportion of new to mature collagen fibers detected in the fibrosis process on the esophageal wall, as described in Kovács et al. ${ }^{3}$. This proportion was determined by the means calculated from ten random sampling sites. The second criterion was the estimate of the total fibrosis percentage detected in the broken tissue. This second criterion was used irrespective of the color acquired by broken tissues in reaction to polarized light, as opposed to non-reacting tissues. Specimens were inspected by a pathologist from the Pathology Service of Clinical Hospital of Porto Alegre who was blinded to the treatment given.

\section{Statistical analysis}

The results of Groups A (total gastrectomy) and B (total gastrectomy and HBO) were compared using the Student's t test with the assistance of the SPSS 12.0 statistical package. Statistical significance was defined as $\mathrm{p}<0.05$, with $90 \%$ statistical power. 


\section{Results}

Twenty rats from Group A (control) and 20 rats from Group B (treated with HBO) received surgery. The mortality rate corresponded to $20 \%$ of the total sample. Five rats were lost in Group A, and three in Group B. In Group A, four rats died from unspecified reasons within the first $24 \mathrm{~h}$ after surgery. A fifth rat died on postoperative day 4 , presenting with stenosis of the anastomostic site.

In Group B, one rat died at the beginning of the laparotomy process, while another died on the first postoperative day from unspecified reasons, and a third rat died 3 days after the surgery due to widespread necrosis in the small intestine. The mechanical parameter of one surgical section of one rat from Group B was not studied, as it was damaged during preparation. Therefore, 31 rats (15 from Group A and 16 from Group B) were analyzed to assess the mechanical parameters of anastomotic healing, while 32 rats (15 from Group A and 17 from Group B) were investigated for the biochemical parameters of anastomotic healing.

One fistula in an esophagojejunal anastomosis was observed in each group of this experiment. Both fistulae were blocked and located on the posterior wall, but did not cause the death of the rats (Figure 1).

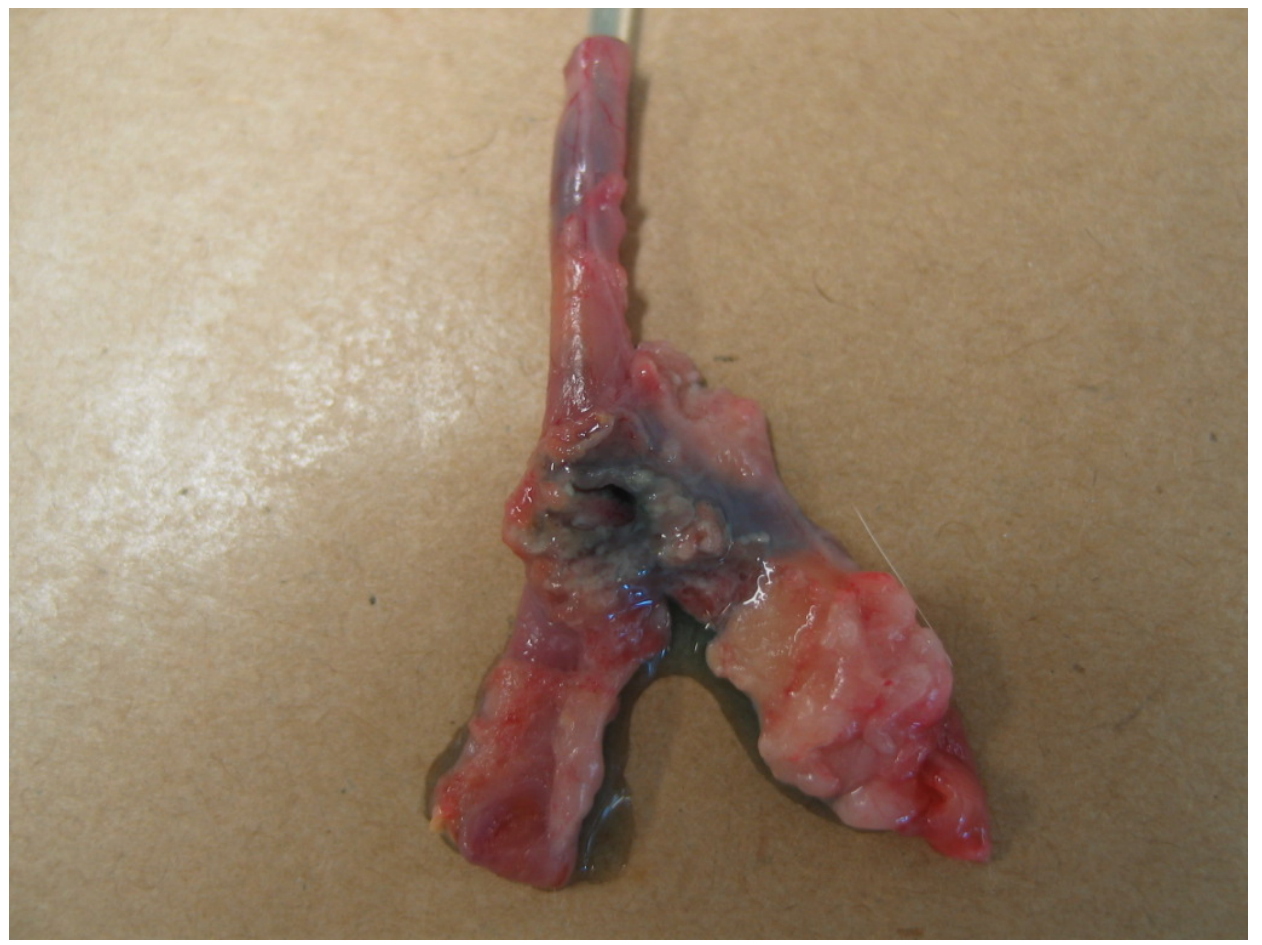

FIGURE 1 - Anastomotic fistulae

Values of suture breaking strength are shown in Table 1.

TABLE 1 - Evaluation of mechanical parameters of anastomotic healing

\begin{tabular}{lccc}
\hline \multicolumn{3}{c}{ Esophagojejunal anastomosis } \\
\hline & $\begin{array}{c}\text { Group A } \\
(\text { control })\end{array}$ & $\begin{array}{c}\text { Group B } \\
(\mathrm{OHB})\end{array}$ & $P$ \\
& $\mathrm{n}=15$ & $\mathrm{n}=16$ & \\
& & & 0.528 \\
Tensile suture & & & \\
sreaking & $1.63 \pm 0.36$ & & \\
strength & & & \\
\hline
\end{tabular}

The comparison between groups did not reveal a statistically significant difference $(\mathrm{p}=0.528)$. All surgical sections broke off at the suture. 
Collagen concentrations found in the anastomotic sites are shown in Table 2.

TABLE 2 - Evaluation of the biochemical parameters of anastomotic healing

\begin{tabular}{llll}
\hline \multicolumn{4}{c}{ Esophagojejunal anastomosis } \\
& $\begin{array}{c}\text { Group A } \\
(\text { control }) \\
n=15\end{array}$ & $\begin{array}{c}\text { Group B } \\
(\mathrm{HBO}) \\
\mathrm{n}=17\end{array}$ & $P$ \\
& & & \\
\hline $\begin{array}{l}\text { Proportion of } \\
\text { fibrosis on the } \\
\text { esophageal } \\
\text { wall } \\
\text { (mean } \pm \text { SD) }\end{array}$ & $40.3 \pm 20.0$ & $39.4 \pm 17.8$ & 0.89 \\
\hline $\begin{array}{l}\text { Proportion of } \\
\text { new collagen } \\
\text { fibers to } \\
\text { fibrosis on the } \\
\text { esophageal } \\
\text { wall } \\
\text { (mean } \pm \text { SD) }\end{array}$ & $24.8 \pm 12.5$ & $29.3 \pm 13.0$ \\
\hline
\end{tabular}

The proportion of fibrosis of the esophageal wall and the proportion of new collagen fibers to fibrosis on the esophageal wall was not statistically significant between Groups A and B ( $p=0.89$ and $p=0.33$, respectively).

The histologic findings are shown in Figures 2 and 3.

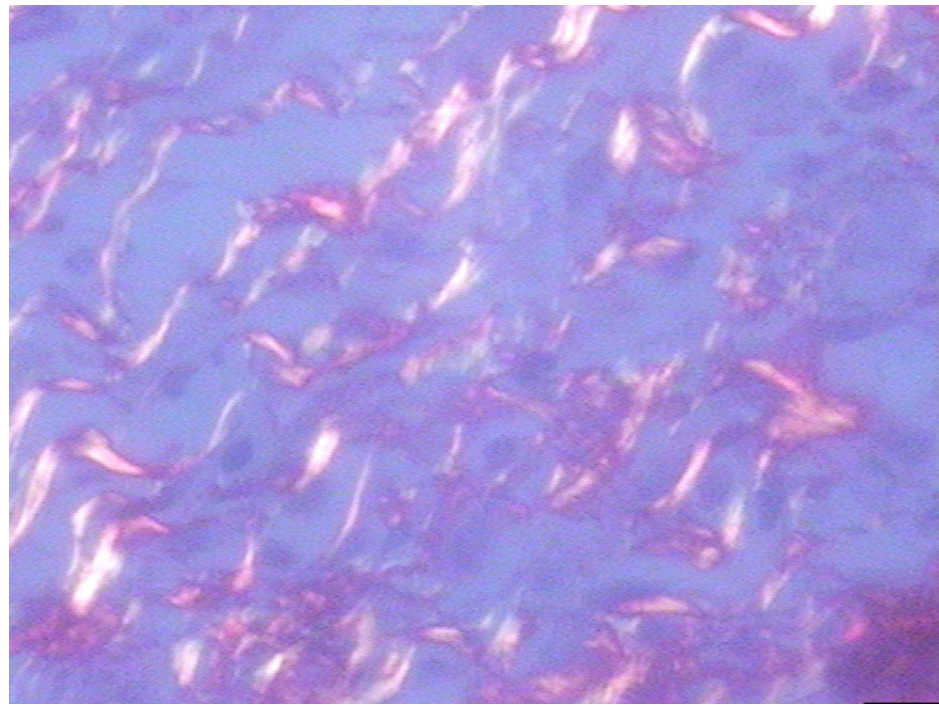

FIGURE 2 - Young collagen fibers

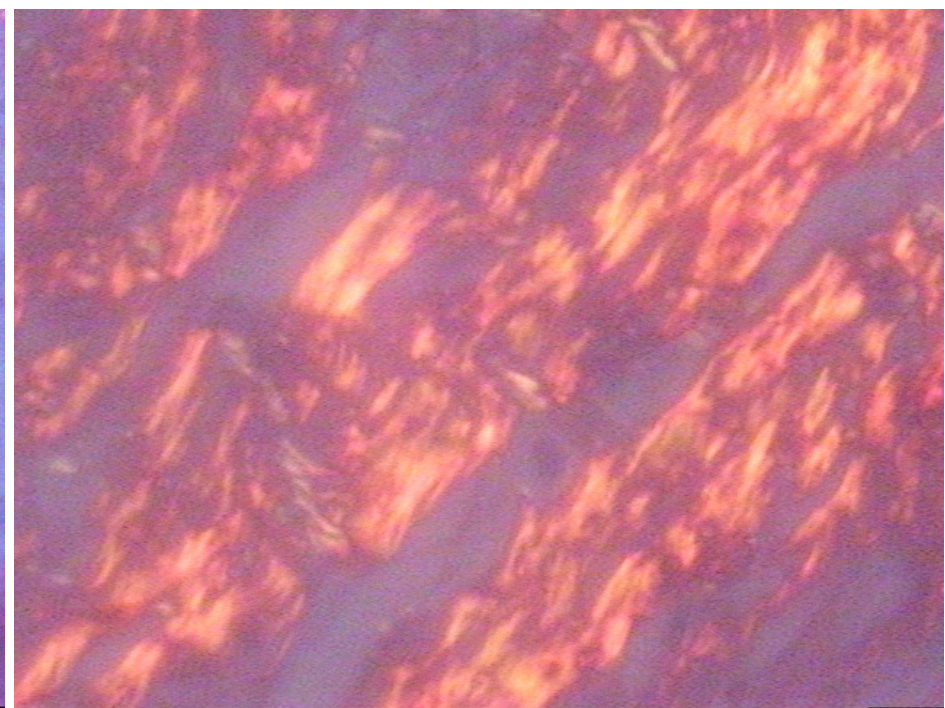

FIGURE 3 - Esophageal wall fibrosis 


\section{Discussion}

Despite progress in surgical techniques and in the development of suture materials, dehiscence are still observed leading to reoperations, prolonged hospital stays, considerable costs, and higher morbidity and mortality rates ${ }^{10}$. Healing is a multifactoral process, the success of which depends on several local and systemic aspects. Among these, local tissue hypoxia is one of the most relevant variables in healing. This is because oxygen molecules are indispensable elements in collagen synthesis and the production of fibroblasts 9 . Diminished blood flow in the surgical incision leads to dehiscence. In this scenario, the correct hypoxemia level secured by the use of hyperbaric oxygen could be seen as an efficient, complementary treatment strategy ${ }^{12}$. The literature lists several publications on the negative effects of poorly oxygenated tissue on healing ${ }^{4,13}$. Nevertheless, few studies have assessed the effect of an increased oxygen uptake to digestive tract anastomotic healing ${ }^{9-10}$.

The mechanical parameters adopted to assess digestive anastomotic healing are tests that determine the intrinsic resistance of sutures as a surrogate of tissue repair. According to Hendriks and Mastboom ${ }^{14}$, the methods most commonly employed for this purpose are: bursting strength under distension by infused air or liquid, and tensile breaking strength. In the present study, we chose to assess tensile breaking strength, also adopted by other authors ${ }^{15-16}$, since the method affords more conclusive results after the seventh postoperative day. Apart from this, the method allows an investigation of healing for up to 28 days $^{10}$. In a study on the healing stages of the large intestine of rats, Hermann et al. found that the third, seventh, and fourteenth postoperative days were the most conclusive ones to study healing ${ }^{2}$.

The measurement of the biochemical parameters was conducted by determining the collagen concentration in anastomotic sites with pricosirius red dye and activation with polarized light, and semi-quantitative inspection under the light microscope. Pricosirius red specifically stains collagen fibers, is easy to handle, and the results are easy to interpret. Contact between pricosirius red and collagen produces intense birefringence which affords a clear visualization of the images obtained. In addition to distinguishing collagen from non-collagen fibers, the dye also characterizes 2 types of collagen fibers: (i) thin collagen fibers, which are new, and (ii) thick fibers, which have reached maturity. This differentiation affords greater efficiency to the histological analysis of these kinds of fibers ${ }^{11,17-18}$.

HBO offers pure oxygen in a pressurized environment. As a rule, the pressure in this kind of environment is set between 2 and 3 ATA. Such exposure may lead to arterial oxygen tension in excess of 2,000 $\mathrm{mmHg}$ and tissue oxygen pressure of $400 \mathrm{mmHg}^{19}$. The benefits of HBO stand on the premise that increased tissue oxygen levels may advance tissue repair ${ }^{20-21}$. Although this notion has gained broad acceptance, the mechanism of action involved in HBO therapy has not yet been thoroughly elucidated ${ }^{9}$. Study models of HBO usage are controversial, and the physiopathologic mechanisms of action during treatment remain unclear, which hampers broad usage of $\mathrm{HBO}$ and makes conclusive results more difficult to determine ${ }^{20-21}$. Studies with human subjects provide evidence that $\mathrm{HBO}$ produces positive results in the promotion of healing in several clinical instances, especially gashes and chronic tissue lesions. Moreover, HBO improves healing by promoting angiogenesis, the proliferation of fibroblasts, and by increasing the bactericidal functions of leukocytes ${ }^{8}$. However, HBO efficiency relies on a minimum number of sessions, optimal pressure values, and appropriate exposure times. Although these parameters may indeed vary depending on prescription variables, study protocols state that sessions of up to 120 minutes and with pressures not exceeding 3 ATA are entirely safe ${ }^{19}$.

Most studies on digestive anastomosis healing using the rat model investigated the small and large intestines, since these organs are experimentally easy to handle. Conversely, studies on esophageal anastomosis are scarce. This may be explained by potentially higher mortality rates due to complications, and by the fact that rodents suffer from early-stage dysfunctions such as the stenosis of anastomosis and other conditions that may become visible later, like malnutrition ${ }^{23}$. Several authors investigated HBO efficiency against ischemic intestinal segments without anastomosis, and reached controversial conclusions as to the benefits the method offers $^{12,24-25}$. Hamzaoglu et al. ${ }^{9}$ assessed the effects of HBO on anastomotic sites in the large intestine of rats. The authors analyzed normal intestines as well as intestines with experimentally induced ischemia, and verified that in the early healing stages, HBO therapy improved both the mechanical and biochemical parameters of anastomotic healing 9 . In a similar study, Yagci, using HBO in the pre- and post-operative period, obtained comparable results ${ }^{10}$.

The results of the present study did not reveal any clinical, mechanical, or biochemical differences between healing of esophagojejunal anastomosis in Wistar rats undergoing total gastrectomy with or without HBO therapy. A comprehensive literature review published in English did not report an experimental model similar to that adopted in this research paper. The model chosen proved its feasibility to study HBO influence in the healing of esophageal anastomosis. Moreover, no advantage of HBO use was detected to prevent complications in esophagojejunal anastomosis. Further research with larger samples and more HBO sessions may shed new light on the importance of HBO therapy in the healing of digestive anastomosis.

\section{Conclusion}

Using clinical, mechanical and biochemical parameters to evaluate esophagojejunal anastomosis, the hyperbaric oxygen therapy did not interfere on healing process.

\section{References}

1. Tannuri U, Tannuri ACA, Fukutaki MF, Oliveira MS, Muoio VMF, Massaguer AA. Effects of circular myotomy on the healing of esophageal suture anastomosis: an experimental study. Rev Hosp Clín Fac Med São Paulo.1999;54:9-16.

2. Caporossi C, Cecconello I, Aguilar-Nascimento JE, Venco F, Gama Rodrigues JJ. Hand-sewn and stapled esophageal anastomoses: experimental study in dogs. Acta Cir Bras. 2004;19(4):319-27.

3. Kovács T, Köves I, Orosz Z, Németh T. Healing of esophageal anastomoses performed with the biofragmentable anastomoses ring versus the end-to-end anastomoses stapler: comparative experimental study in dogs. World Surg. 2003; 27:465-72.

4. Thornton FJ, Barbul A. Healing in the gastrointestinal tract. Surg Clin North Am. 1997;77(3):549-73.

5. Cui Y, Urschel JD. Comparision of anastomotic suturing techniques in the rat esophagus. J Cardiovasc Surg. 1999;40:613-4. 
6. Kovács T, Köves I, Pandi E, Németh T, Kralovansky J. Bursting strength and collagen content changes in esophageal anastomosis: comparative experimental study in dogs. Ann Chirur Gynaecol. 2001;90:266-70.

7. Okur H, Küçükaydin N, Kontaf O, Küçükaydin M, Özokutan BH. Esophageal anastomosis: an experimental model to study anastomotic healing and the use of lyophilized collagen. Res Exp Med. 1996;195:275-80. 8. Mechem CC, Manaker S. Hyperbaric oxygen therapy Up To Date 2006. Available from URL: http// www.uptodate.com [Access in august 2006]. 9. Hamzaoglu I, Karahasanoglu T, Aydin S, Sahin D, Carkman S, Sariyar $\mathrm{M}$, Alendaroglu K. The effects of hyperbaric oxygen on normal and ischemic colon anastomoses. Am J Surg. 1998;176:458-61.

10. Iagci G, Ozturk E, Ozgurtas T, Gorgulo S, Kutlu OC, Topal T, Cetiner S, Tufan T.Preoperative and posoperative administration of hyperbaric oxygen improves biochemical and mechanical parameters on ischemicannormal colonic anastomoses. J Invest Surg. 2006;19(4):237-44.

11. Rabau MY, Dayan D. Polarization microscopy of picrosirius red stained sections:a useful method for qualitative evaluation of intestinal wall collagen. Histol Histopathol. 1994;9:525-8.

12. Rocha AA, Coy CSR, Góes JRN, Ayrizono MLS, Wu FC, Fagundes JJ. Estudo comparativo da hiperoxigenação hiperbárica em alças cólicas isquêmicas em ratos. Acta Cir Bras. 2005; 20(2):152-8.

13. Hunt TK, Pai MP. The effect of varing ambient oxygen tensions on wound metabolism and collagen synthesis. Surg Gynecol Obstet. 1972;135: 561-7.

14. Hendriks T, Mastboom WJB. Healing of experimental intestinal anastomoses: parameters for repair. Dis Colon Rectum. 1990;33:891-901. 15. Jiborn H, Ahonen J, Zederfeldt B. Healing of experimental colonic anastomoses. II. Breaking strength of the colon after left colon resection and anastomoses. Am J Surg. 1978;136:595-9.
16. Blomquist $\mathrm{P}$, Jiborn $\mathrm{H}$, Zederfeldt $\mathrm{B}$. The effect of relative bowel resto $\mathrm{n}$ healing of colonic anastomoses: breaking strengh and collagen in the colonic wall following left colon ressection and anastomoses in the rat. Acta Chir Scand. 1984;150:671-5.

17. Junqueira LC, Bignolas G, Brentani RR. Picrosirius staining plus polarization microcopy, a specific method for collagen detection in tissue section. Histochemistry J. 1979;11:447-55.

18. Junqueira LC, Montes GS, Sanches EM. The influence of tissue section thickness on the study of collagen by the Picrosirius-polarization method. Histochemistry. 1982;74:153-6.

19. Tibbles P, Edelsberg J. Hyperbaric- oxygen therapy. N Engl J Med. 1996;334:1642-8.

20. Méchine A, Rohr S, Toti F, Aysoy C, Schneider F, Meyer Ch, Tempé JD, BellocqJP. La cicatrisation sous oxygénothérapie hyperbare: étude expérimentale de as phase angiogénique chez le rat. Ann Chir. 1999;53(4):307-13.

21. Wang C, Schwaitzberg S, Berliner E, Zarin DA, Lau J. Hyperbaric oxygen for treating wounds. Arch Surg. 2003;138:272-9.

22. Cui Y, Urschel JD. Esophagogastric anastomotic wound healing in rats. Dis Esophagus. 1999;12:149-51.

23. Levi A, Ramadan E, Gelber E, Koren R, Chainoff C, Kyzer S. Healing of the esophageal suture line: does it differ from the rest of the alimentary tract? Isr J Med Sci. 1996;329(12):1313-6.

24. Dockendorf BL, Frazee RC, Peterson WG, Myers D. Treatment of acute intestinal ischemia with hyperbaric oxygen. South Med J. 1993;86:518-22.

25. Yamada T, Taguchi T, Hirata Y, Suita S, Yagi H. The protective effect of hyperbaric oxygenation on the small intestine in ischemia-reperfusion injury. J Pediatr Surg. 1995;30(6):786-90.

Conflict of interest: none Financial source: none

\section{Correspondence:}

João Domingos Lionço

Rua Garibaldi, 461/51

95080-190 Caxias do Sul - RS Brazil

Phone: (55 54)3221-4517

jdlionco@yahoo.com.br

Received: May 19, 2008

Review: July 21, 2008

Accepted: August 26, 2008

\section{How to cite this article}

Lionço JD, Lionço LC, Filippi LT, Lionço CC, Volkweiss B, Gurski RR. Effect of hyperbaric oxygen therapy on esophagojejunal anastomosis healing in rats. Acta Cir Bras. [serial on the Internet] 2008 Nov-Dec;23(6). Available from URL: http://www.scielo.br/acb

*Color figures available from www.scielo.br/acb 